\title{
Dampak Pemilihan Umum Serentak Bagi Pembangunan Demokrasi Indonesia
}

\author{
Whindy Salsa Nabila \\ IIK STRADA INDONESIA \\ whindysalsanabila@gmail.com
}

\begin{abstract}
Abstrak
Pemilu adalah mekanisme demokrasi untuk memilih seseorang yang akan mewakili rakyat dan memimpin pemerintahan. Sejak 1955, Indonesia telah menyelenggarakan 11 pemilu. Berdasarkan UUD 1945 pasal 1 ayat 3, memberikan hak kepada rakyat untuk menentukan kekuasaan. Pada tahun 2014, Indonesia telah menyelenggarakan pemilihan umum untuk memilih anggota parlemen dan presiden yang digelar dihari yang berbeda. Sebulan sebelum pemilihan umum dilakukan, Mahkamah Konstitusi mengumumkan peninjauan pengujian Undang-undang Nomor 42 Tahun 2008. Mahkamah Konstitusi memutuskan pemilihan legislatif dan pemilihan presiden dan wakil presiden yang digelar serentak. Keputusan Mahkamah Konstitusi No 14/PUUXI/ 2013 memiliki implikasi hukum pada pemilihan umum 2014 dan juga mepilihan umum 2019. Sejak awal hukum baru disahkan, KPU telah membuat semua persiapan untuk menyelenggarakan pemilihan secara serentak di Indonesia. Tujuan utamanya adalah untuk mengurangi biaya. Kualitas demokrasi tergantung kepada keadilan bukan kepada biaya yang dihabiskan. Hal ini penting untuk memastikan keadilan dan pada waktu yang bersamaan juga menghindari terjadinya konflik yang mungkin terjadi.
\end{abstract}

\section{Kata kunci: Demokrasi dan Pemilu serentak}

\section{Latar Belakang}

Pemilu adalah wujud nyata demokrasi prosedural, meskipun demokrasi tidak sama dengan pemilihan umum, namun pemilihan umum merupakan salah satu aspek demokrasi yang sangat penting yang juga harus diselenggarakan secara demokratis. Oleh karena itu, lazimnya di negara-negara yang menamakan diri sebagai negara demokrasi mentradisikan
Pemilu untuk memilih pejabat-pejabat publik di bidang legislatif dan eksekutif baik di pusat maupun daerah. Demokrasi dan Pemilu yang demokratis saling merupakan "qonditio sine qua non", the one can not exist without the others. Dalam arti bahwa Pemilu dimaknai sebagai prosedur untuk mencapai demokrasi atau merupakan prosedur untuk memindahkan kedaulatan rakyat kepada 
kandidat tertentu untuk menduduki jabatan-jabatan politik (Veri Junaidi, 2009: 106). Pemilu menunjukkan bahwa kekuasaan politik berasal dari rakyat dan dipercayakan demi kepentingan rakyat, dan bahwa kepada rakyatlah para pejabat bertanggung jawab atas tindakantindakannya (David Bentham dan Kevin Boyle, 2000). Selanjutnya Moh. Mahfud mengatakan bahwa kedaulatan rakyat mengandung pengertian adanya pemerintahan dari, oleh dan untuk rakyat, menunjukkan bahwa pemerintahan dari rakyat mengandung pengertian yang berhubungan dengan pemerintahan yang sah dan diakui (legitimate government) di mata rakyat (Moh. Mahfud MD, 1999). Pemerintahan yang sah dan diakui berarti suatu pemerintahan yang mendapat pengakuan dan dukungan yang diberikan oleh rakyat. Legitimasi bagi suatu pemerintahan sangat penting karena dengan legitimasi tersebut, pemerintahan dapat menjalankan roda birokrasi dan program-programnya sebagai wujud dari amanat yang diberikan oleh rakyat kepadanya (Tim ICCE UIN Jakarta, 2003). Pemerintahan dari rakyat memberikan gambaran bahwa pemerintah yang sedang memegang kekuasaan dituntut kesadarannya bahwa pemerintahan tersebut diperoleh melalui pemilihan dari rakyat bukan dari pemberian wangsit.

\section{Kasus/Masalah}

Bagaimana dampak dari sistem pemilihan umum serentak untuk mengembangkan demokrasi di Indonesia?

\section{Tinjauan Pustaka}

Pemilu adalah wujud nyata demokrasi prosedural, meskipun demokrasi tidak sama dengan pemilihan umum, namun pemilihan umum merupakan salah satu aspek demokrasi yang sangat penting yang juga harus diselenggarakan secara demokratis. Pemilu menunjukkan bahwa kekuasaan politik berasal dari rakyat dan dipercayakan demi kepentingan rakyat, dan bahwa kepada rakyatlah para pejabat bertanggung jawab atas tindakantindakannya (David Bentham dan Kevin Boyle, 2000). Selanjutnya Moh. Mahfud mengatakan bahwa kedaulatan rakyat mengandung pengertian adanya pemerintahan dari, oleh dan untuk rakyat, menunjukkan bahwa pemerintahan dari rakyat mengandung pengertian yang berhubungan dengan pemerintahan yang sah dan diakui (legitimate government) di mata rakyat (Moh. Mahfud MD, 1999).

\section{Pembahasan}

A. Pemilihan Umum di Indonesia

Pemilihan Umum dilaksanakan di Indonesia untuk memilih anggota lembaga perwakilan, presiden dan wakil presiden. 
Konstitusi dalam Pasal 22E UUD 1945 mengatur ketentuan tentang Pemilu secara jelas dan detail, sebagai berikut:

1) Pemilihan umum dilaksanakan secara langsung, umum, bebas, rahasia, jujur, dan adil setiap lima tahun sekali. 2) Pemilihan umum diselenggarakan untuk memilih anggota Dewan Perwakilan Rakyat, Dewan Perwakilan Daerah, Presiden dan Wakil Presiden dan Dewan Perwakilan Rakyat Daerah. 3) Peserta pemilihan umum untuk memilih anggota Dewan Perwakilan Rakyat dan anggota Dewan Perwakilan Rakyat Daerah adalah partai politik. 4) Peserta pemilihan umum untuk memilih anggota Dewan Perwakilan Daerah adalah perseorangan. 5) Pemilihan umum diselenggarakan oleh suatu komisi pemilihan umum yang bersifat nasional, tetap, dan mandiri. 6) Ketentuan lebih lanjut tentang pemilihan umum diatur dengan undang-undang

\section{B. Pemilu Serentak}

Di Indonesia saat ini, menggunakan sistem pemilu berkala, yaitu antara sistem pemilu legislatif (DPR, DPD, DPRD Provinsi, dan DPRD Kabupaten/Kota) terpisah dengan pemilu presiden dan wakil presiden, ditambah dengan pemilu kepala daerah. Alasannya, menurut Assiddiqie, yaitu: (1) perubahan atas sikap dan pendapat masyarakat sebagai aspirasi dalam memilih pemimpin dan wakilnya di parlemen; (2) kondisi dan aspek kehidupan masyarakat juga mengalami perubahan sesuai dengan kondisi dan situasi, tergantung dari lingkungan yang mempengaruhinya. Artinya, ada beberapa faktor yang dapat merubah aspirasinya, yaitu karena faktor dinamika dalam lingkungan lokal atau dalam negeri, atau dunia international, baik karena faktor internal maupun eksternal masyarakat itu sendiri; (3) meningkatnya pertumbuhan penduduk, dapat juga mempengaruhi aspirasi rakyat; dan (4) diperlukannya pemilu secara teratur untuk ritme pemerintahan yang lebih baik.

Putusan Mahkamah Konstitusi No.14/PUU-XI/2013 merupakan pengujian Pasal 3 ayat (5), Pasal 12 ayat (1) dan ayat (2), Pasal 14 ayat (2), dan Pasal 112 Undang-Undang No.42 Tahun 2008 tentang Pemilihan Umum Presiden dan Wakil Presiden. Beberapa pasal tersebut mengatur ketentuan Pemilu Anggota Lembaga Perwakilan dan Pemilihan Presiden yang dilaksanakan terpisah, namun berdasar putusan Mahkamah Konstitusi ketentuan beberapa pasal tersebut dinyatakan bertentangan dengan UUD 1945 dan tidak mempunyai kekuatan hukum mengikat. Implikasi dari pembatalan tersebut adalah dilaksanakannya "Pemilihan Umum 
Nasional Serentak" atau Pemilu Anggota Lembaga Perwakilan dan Pemilihan Presiden dilakukan secara serentak yang dimulai pada tahun 2019 dan tahun-tahun selanjutnya. Putusan ini menarik dan sesuai dengan perkembangan ketatanegaraan Indonesia yang semakin demokratis, Mahkamah Konstitusi sebagai lembaga pengawal demokrasi dan satusatunya lembaga penafsir konstitusi memiliki kewenangan untuk menata sistem ketatanegaraan dan demokratisasi yang mengarah pada idealisasi sistem pemilu di Indonesia melalui pengujian undangundang. Perkembangan demokratisasi di Indonesia pasca reformasi memang telah melaju kencang, misalnya Pilpres langsung. Menurut Mahkamah Konstitusi bahwa dalam penyelenggaraan Pilpres tahun 2004 dan tahun 2009 yang dilakukan setelah Pemilu Anggota Lembaga Perwakilan ditemukan fakta politik bahwa untuk mendapat dukungan demi keterpilihan sebagai Presiden dan dukungan DPR dalam penyelenggaraan pemerintahan, jika terpilih calon Presiden terpaksa harus melakukan negosiasi dan tawar-menawar (bargaining) politik terlebih dahulu dengan partai politik yang berakibat sangat mempengaruhi jalannya roda pemerintahan di kemudian hari. Negosiasi dan tawar-menawar tersebut pada kenyataannya lebih banyak bersifat taktis dan sesaat daripada bersifat strategis dan jangka panjang, misalnya karena persamaan garis perjuangan partai politik jangka panjang. Oleh karena itu, Presiden pada faktanya menjadi sangat tergantung pada partai-partai politik sehingga dapat mereduksi posisi Presiden dalam menjalankan kekuasaan pemerintahan menurut sistem pemerintahan presidensial. Dengan demikian penyelenggaraan Pilpres harus menghindari terjadinya negosiasi dan tawar-menawar (bargaining) politik yang bersifat taktis demi kepentingan sesaat, sehingga tercipta negosiasi dan koalisi strategis partai politik untuk kepentingan jangka panjang. Mahkamah Konstitusi bertujuan menata sistem pemilu lebih baik dan mampu melahirkan presiden dan wakil presiden yang berkualitas, serta mampu menyelesaian persoalan bangsa dan negara. Pilpres yang dilakukan setelah Pemilu Legislatif (Pemilu tidak serentak) telah menyebabkan sistem pemilu dan sistem pemerintahan presidensiil keluar dari rel konstitusi, sehingga untuk mengembalikan hal tersebut pada sistem yang benar menurut konstitusi harus dengan membatalkan beberapa ketentuan Pasal dalam UU Pilpres yang mengatur hal tersebut. Menurut Mahkamah Konstitusi bahwa norma pelaksanaan Pilpres yang dilakukan setelah Pemilu Legislatif telah nyata tidak sesuai dengan semangat yang dikandung oleh UUD 1945 dan tidak sesuai dengan makna pemilihan umum 
yang dimaksud oleh UUD 1945, khususnya dalam Pasal 22E ayat (1) UUD 1945 yang menyatakan, "Pemilihan umum dilaksanakan secara langsung, umum, bebas, rahasia, jujur, dan adil setiap lima tahun sekali” dan Pasal 22E ayat (2) UUD 1945 yang menyatakan, "Pemilihan umum diselenggarakan untuk memilih anggota Dewan Perwakilan Rakyat, Dewan Perwakilan Daerah, Presiden dan Wakil Presiden dan Dewan Perwakilan Rakyat Daerah", serta Pasal 1 ayat (2) UUD 1945 yang menyatakan, "Kedaulatan berada di tangan rakyat dan dilaksanakan menurut UUD”. Artinya pemilu yang tidak serentak menurut UU Pilpres tersebut bertentangan dengan UUD 1945, namun dalam dasar pertimbangan Mahkamah Konstitusi bahwa penyelenggaraan Pilpres dan Pemilu Anggota Lembaga Perwakilan tahun 2009 dan 2014 yang diselenggarakan secara tidak serentak dengan segala akibat hukumnya harus tetap dinyatakan sah dan konstitusional. Adapun argumentasi Mahkamah Konstitusi bahwa Pasal 3 ayat (5), Pasal 12 ayat (1) dan ayat (2), Pasal 14 ayat (2), dan Pasal 112 Undang-undang No.42 Tahun 2008 bertentangan dengan UUD 1945 didasarkan pada tiga pertimbangan pokok, yaitu kaitan antara sistem pemilihan dan pilihan sistem pemerintahan presidensial, original intent dari pembentuk UUD 1945, efektivitas dan efisiensi penyelenggaraan pemilihan umum, serta hak warga negara untuk memilih secara cerdas.

Pemilu nasional serentak tidak hanya memberikan implikasi pada ranah hukum tata negara atau politik ketatanegaraan saja, tetapi memiliki implikasi yang besar dalam kajian ilmu politik. Dalam perspektif ilmu politik, pemilu nasional serentak memiliki sejumlah keuntungan yang bersifat hipotetik dilihat dari sisi pelembagaan politik dan konsolidasi demokrasi di Indonesia, meliputi:

1. Pemilu nasional serentak bertujuan menciptakan hasil pemilu yang kongruen Secara akademis konsep pemilu serentak ini hanya memungkinkan berlaku dalam sistem pemerintahan presidensial. Inti konsep ini adalah menggabungkan pelaksanaan pemilu legislatif dan eksekutif dalam satu hari yang sama, sehingga kemungkinan terciptanya pemerintahan yang kongruen, maksudnya terpilihnya pejabat eksekutif (Presiden dan Wakil Presiden) yang mendapat dukungan legislatif sehingga pemerintahan stabil dan efektif. Kongruensi pemerintahan yang tercipta ini diasumsikan akan berkorelasi secara signifikan terhadap stabilitas dan efektivitas pemerintahan. Pemerintahan diharapkan akan efektif dalam pengambilan keputusan karena mayoritas kursi parlemen dipegang oleh partai yang mengusung presiden terpilih. Inilah yang 
sering diasumsikan bahwa pemilu serentak berkorelasi positif terhadap penguatan presidensialisme di Indonesia. Konsep dan desain ini didasarkan pengalaman Negaranegara Amerika Latin yang menggunakan sistem pemilu presidensial dengan pemilu tidak serentak yang mengakibatkan pemerintahannya tidak stabil akibat pertikaian antara presiden terpilih dengan parlemen yang mayoritas anggotanya tidak berasal dari partainya presiden atau partai koalisi pendukung presiden. Untuk mengatasi persoalan ini, Brasil kemudian mengadakan pemilu serentak mulai 1994 dan dalam waktu 15 tahun kemudian Brasil menunjukkan stabilitasnya, dan bahkan menjadi salah satu kekuatan ekonomi dunia saat ini. Sukses Negara Brasil kemudian diikuti oleh banyak Negara di kawasan itu. Menurut Shugart, kongruensi ini tercipta karena dalam pemilu serentak terdapat efek yang namanya coattail effect, di mana keterpilihan calon presiden akan mempengaruhi keterpilihan calon legislative (Mattew Soberg Shugart dan Scott Mainwaring, 1997). Artinya, orang setelah memilih capres akan cenderung memberikan pilihannya terhadap legislatif yang berasal dari partai yang mengusung presiden (Heather Stoll, 2011).

2. Pemilu nasional serentak ini mendorong terciptanya koalisi berbasis kebijakan
Pemilu nasional serentak ini mendorong terciptanya koalisi berbasis kebijakan, sebab pemilu juga membutuhkan partai politik yang kuat dan daya tahan memadai dalam mewakili kepentingan masyarakat dan menawarkan pilihan-pilihan kebijakan untuk menunjukkan kemampuannya dalam menuju kebaikan umum (bonum publicum) (A.Ahsin Tohari, 2012: 580), dan sekaligus meminimalkan pragmatisme politik yang kerap menjadi acuan aktoraktor dan partai-partai politik dalam berkoalisi. Sebagaimana yang terjadi saat ini, pemilu model serial/ tidak serentak sangat rawan pragmatisme politik karena parpol bergabung dalam sebuah koalisi cenderung untuk mendapatkan kekuasaan (office-oriented approach), bukan karena memperjuangkan kebijakan (policyoriented approach). Berdasarkan putusan Mahkamah Konstitusi tersebut di atas pelaksanaan pemilu yang tidak serentak membuat pengawasan maupun checks and balances antara DPR dan Presiden tidak berjalan dengan baik. Sebab, pasangan calon presiden dan wakil presiden kerap menciptakan koalisi taktis yang bersifat sesaat dengan partai-partai politik. Apa yang terjadi dalam dua kali pelaksanaan pemilihan preisden ini tidak melahirkan koalisi jangka panjang yang dapat melahirkan penyederhanaan partai politik secara alamiah. Dengan pemilu serentak, parpol tak bisa lagi berkoalisi 
secara pragmatis. Parpol akan lebih selektif mencari calon, dan tak sekadar mengandalkan pertimbangan matematis. Dalam jangka panjang, hal ini diharapkan bermuara pada penyederhanaan sistem kepartaian secara alamiah.

3. Pemilu nasional serentak mendorong kualitas Parpol yang lebih demokratis Kehadiran dan peran partai politik saat ini menjadi prasyarat penting bagi praktik demokrasi modern, bahkan demokrasi modern adalah demokrasi partai (Richard S Katz, 1980). Literatur studi demokrasi umumnya menyebut adanya partai politik yang bebas, otonom, dan kompetitif merupakan conditio sine quo non bagi praktik demokrasi. Sistem politik demokratis diyakini mampu memfasilitasi kehidupan partai politik yang bebas, otonom, dan kompetitif, maka demokratisasi partai politik mensyaratkan demokratisasi sistem politik terlebih dulu. Tanpa sistem politik demokratis, sulit muncul partai politik yang bebas, otonom, dan kompetitif. Dalam sistem politik nondemokratis, kehidupan partai politik umumnya tidak bebas, tidak otonom, dan tidak kompetitif (Munafrizal Manan, 2012). Sebagai saluran utama pengajuan pasangan calon presiden dan wakil presiden, demokratisasi internal partai politik menjadi sebuah keniscayaan. Artinya, pasangan calon yang diajukan harus berasal dari hasil sebuah proses yang terbuka dan partisipatif. Dengan cara seperti itu, posisi sentral (seperti ketua umum, ketua dewan pembina dan lainlain) di partai politik tidak otomatis menjadi jalan tol menjadi calon presiden dan/atau wakil presiden. Melihat realitas empirik selama ini, mengharapkan semua partai politik untuk lebih demokratis. Karena itu, tidak ada pilihan lain, kecuali Undang-undang tentang Partai Politik memberikan paksaan yang tak mungkin dihindari. Dalam hal ini, undang-undang tersebut harus menentukan kerangka dasar keterbukaan proses pengajuan pasangan calon. Jika perlu, sekiranya tidak melakukan proses terbuka dan partisipatif, partai politik bersangkutan kehilangan haknya mengajukan pasangan calon.

4. Pemilu nasional serentak potensial meminimalkan konflik antar partai atau pendukung partai. Konflik tak lagi berkepanjangan sepanjang tahun, sehingga dari sisi manajemen konflik jadi lebih mudah untuk ditangani. Energi pendukung partai dapat diarahkan untuk kegiatan positif lain yang mengarah pada pelembagaan partai politik. Bahkan pemilu nasional serentak lebih efisien, hemat waktu dan hemat biaya. Efisiensi dalam konteks pemilu serentak ini bisa dilihat dari beberapa aspek, antara lain efisiensi waktu dan biaya pemilu. Trilyunan uang 
negara dapat dialihkan untuk memenuhi hak konstitusional lain yang tidak kalah penting, sebab dalam tahapan pemilu legislatif dan presiden yang bersamaan/ serentak banyak hal yang bisa diringkas dalam satu paket pekerjaan. Apalagi sekitar $65 \%$ biaya pemilu dialokasikan untuk honor petugas pemilu, sehingga makin banyak pemilu digelar, maka makin besar biaya yang dikeluarkan. Selanjutnya dalam aspek efisiensi biaya politik, karena biaya kampanye caleg dan capres jadi satu maka politik biaya tinggi sebagaimana praktik yang terjadi saat ini bisa diminimalkan. Dampak positif lebih lanjut, berpotensi kurangi money politics dan korupsi, sebab strategi pemenangan kandidat dengan menggunakan praktik politik uang memunculkan persaingan tidak sehat dalam pemilu karena memunculkan lapangan bermain yang tidak sama (un equity of playing field), ketimpangan akses menuju pucuk pimpinan jabatan publik, dan lahirnya politik yang terkooptasi yang menurunkan kualitas demokrasi, dan mengorbankan kepentingan public (Devi Darmawan, 2012). Selain itu, dengan pemilu nasional serentak akan terjadi perubahan drastis mengenai presidential threshold, sebab semua partai politik yang lolos menjadi peserta pemilu akan bisa mengajukan calon presiden dan calon wakil presiden. Bahkan, bisa jadi akan masuk juga calon presiden independen (Sudarto Danusubroto). Menurut Didik Supriyanto sebagaimana dikutip Ria Casmi Arrsa (Ria Casmi Arrsa, 2014: 532-533) bahwa gagasan Pemilu serentak mampu mengatasi politik dinasti dengan dasar argumentasi Pertama, bila pemilu legislatif dan pemilu eksekutif dilaksanakan bersamaan, setiap orang (termasuk petahana dan kerabatnya) memiliki peluang terbatas untuk mencalonkan diri. Mereka harus memilih salah satu jabatan yang hendak digapai: anggota legislatif atau jabatan eksekutif. Baik yang terpilih maupun yang tidak berada dalam posisi sama dalam kurun lima tahun ke depan. Bandingkan dengan situasi saat ini. Pada saat pemilu legislatif, setiap orang memburu kursi DPR, DPD, dan DPRD. Selang satu atau dua tahun kemudian, mereka yang sudah mendapat kursi parlemen maupun yang gagal bergerak ke arena eksekutif berebut kursi kepala daerah dalam pilkada. Bagi pemilik kursi parlemen yang gagal bisa kembali menduduki kursinya; sedangkanyang berhasil akan meninggalkan kursinya untuk orang lain, yang bisa jadi adalah kerabatnya. Kedua, penggabungan pemilu legislatif dan pemilu eksekutif memaksa partai-partai politik membangun koalisi sejak dini. Mereka sadar, keterpilihan calon pejabat eksekutif yang mereka usung akan memengaruhi keterpilihan calon- 
calon anggota legislatif. Hal ini mendorong partaipartai akan membangun koalisi besar sehingga pasca pemilu menghasilkan blocking politic di satu pihak, terdapat koalisi besar yang memenangi jabatan eksekutif sekaligus menguasai kursi parlemen; di pihak lain terdapat koalisi gagal meraih jabatan eksekutif yang menjadi kelompok minoritas parlemen sehingga mau tidak mau menjadi oposisi. Dengan demikian melalui gagasan Pemilu serentak diharapkan menjadikan suatu upaya untuk membangunan kualitas demokrasi yang terkonsolidasi sehingga secara simultan akan berdampak pada menguatnya sistem Presidensil di Indonesia.

\section{Kesimpulan}

Tujuan Pemilu dan demokratisnya sebuah Pemilu, juga terdapat fungsi pemilu yang tidak bisa dipisahkan satu sama lain, yaitu: (1) sebagai sarana legitimasi politik, terutama menjadi kebutuhan pemerintah dan sistem politik untuk mendapatkan sumber otoritas dan kekuatan politiknya. (2) fungsi perwakilan rakyat. Pemilu nasional serentak memiliki sejumlah keuntungan yang bersifat hipotetik dilihat dari sisi pelembagaan politik dan konsolidasi demokrasi di Indonesia, meliputi: (1) Pemilu nasional serentak bertujuan menciptakan hasil pemilu yang kongruen; (2) Pemilu nasional serentak ini mendorong terciptanya koalisi berbasis kebijakan; (3) Pemilu nasional serentak mendorong kualitas Parpol yang lebih demokratis; (4) Pemilu nasional serentak potensial meminimalkan konflik antar partai atau pendukung partai. Konflik tak lagi berkepanjangan sepanjang tahun, sehingga dari sisi manajemen konflik jadi lebih mudah untuk ditangani. Energi pendukung partai dapat diarahkan untuk kegiatan positif lain yang mengarah pada pelembagaan partai politik.

\section{Daftar Pustaka}

A.Ahsin Thohari. (2012). Deklinasi Partai Politik dalam Sistem Ketatanegaraan Indonesia. Jurnal Legislasi Indonesia Vol. 9 No. 4 Desember 2012.

Prasetyoningsih, N. (2014). Dampak Pemilihan Umum serentak bagi pembangunan demokrasi Indonesia. Jurnal Media Hukum, 21(2), 23.

Ria Casmi Arrsa. (2014). Pemilu Serentak dan Masa Depan Konsolidasi Demokrasi. Jurnal Konstitusi, Volume 11, Nomor 3, September 2014.

Karina, Z., \& Sodik, M. A. (2018). Pengaruh Dukungan Sosial Terhadap Kesehatan.

NABILA, W. S. (2021, October 27). TOLERANSI DALAM UMAT BERAGAMA DALAM 
MEMPERKOKOH PERSATUAN DAN

KESATUAN BANGSA. 